\title{
Konstruksi Pseudo Berdasarkan Kecenderungan Pengetahuan Prosedural
}

\author{
Herna \\ Universitas Sulawesi Barat; \\ e-mail: hernaruhu105@gmail.com
}

\begin{abstract}
Abstrak
Penelitian kualitatif ini dilakukan pada siswa kelas VIII. Tujuannya adalah mengkaji proses konstruksi pseudo benar dan salah berdasarkan kecenderungan pengetahuan prosedural, dan menetapkan karakteristiknya.Peneliti menemukan bahwa Konstruksi pseudo benar ketika siswa menyelesaikan operasi penjumlahan pecahan bentuk aljabar terjadi ketika siswa memberikan jawaban yang benar dengan prosedur penyelesaian yang benar, tetapi siswa tidak mampu memberikan justifikasi terhadap prosedur yang digunakan.Konstruksi pseudo salah terjadi dalam dua kondisi.Pertama, kondisi ketika siswa memberikan jawaban yang salah dengan prosedur penyelesaian yang salah, karena siswa terdorong untuk menjawab dengan cepat.Kedua, kondisi ketika siswa memberikan jawaban yang salah karena careless error dengan prosedur penyelesaian yang benar, dan siswa mampu memberikan justifikasi terhadap prosedur yang digunakan.
\end{abstract}

Kata kunci : Konstruksi pseudo, Pengetahuan prosedural, Pecahan bentuk aljabar

\section{PENDAHULUAN}

Terjadi konstruksi konsep dan penyelesaian masalah matematika pada siswa dalam proses belajar matematika. Konstruksi tersebut bisa berhasil atau gagal. Konstruksi konsep dikatakan berhasil jika proses konstruksi benar dan pemahaman terhadap konsep tersebut baik, begitu pun sebaliknya. Sedangkan konstruksi penyelesaian masalah dikatakan berhasil jika ditemukan hasil yang benar dengan proses penyelesaian yang benar. Selanjutnya, konstruksi penyelesaian masalah dikatakan gagal jika, ditemukanhasil yang salah dengan proses penyelesaian yang salah, ditemukan hasil yang benar dengan proses penyelesaian yang salah, dan ditemukan hasil yang salah padahal sebenarnya mampu menemukan proses penyelesaian yang benar. Konstruksi yang gagal menunjukkan adanya kesulitan siswa dalam mengonstruksi konsep dan menyelesaikan masalah matematika.Kesulitan tersebut seringkali tercermin dalam bentuk kesalahan yang dibuat oleh siswa. Kesalahan tersebut dapat berupa hasil yang tampak dari proses konstruksi bukan merupakan keluaran dari aktivitas mental yang sesungguhnya (Herna, dkk., 2016; Leron, 2005; Lithner, 2000; Pape, 2004; Subanji \& Nusantara, 2013; Vinner, 1997). Kondisi seperti itu akan disebut sebagai konstruksi pseudo dalam penelitian ini.

Konstruksi pseudo telah dikaji oleh banyak peneliti dengan menggunakan istilah yang berbeda-beda. Herna, dkk. (2016) menggunakan istilah yang sama yakni, pseudo contruction (konstruksi pseudo) dalam konteks memahami konsep limit fungsi,Subanji $(2007,2011)$ menggunakan istilah berpikir pseudo dalam penalaran kovariasional, Vinner (1997) menggunakan istilah pseudo-analytic dan pseudo-conceptual, Lithner (2000) menggunakan istilah established experience (EE) versus Plausible Reasoning (PR) dalam konteks pemecahan soal non rutin, Leron (2005) mengkaji Dual process Theory dari Kahneman (proses sistem 1 versus proses sistem 2) dalam konteks pemecahan masalah aljabar, dan Pape (2004) menggunakan istilah direct Translation Approach (DTA) versus Meaning Based Approach (MBA) dalam konteks pemecahan soal cerita. 
Sumber kesalahan dalam mengonstruksi konsep dan memecahkan masalah matematika adalah terjadi kesalahan matematika dalam melakukan aktivitas tersebut (Barrera, dkk., 2004; Dhlamini, 2014; Elbrink, 2007; Ganesan \& Dindyal, 2014; Godden, dkk., 2013; Herna, 2018; Huang \& Cheng, 2010; Idris \& Narayanan, 2011; Kiat, 2005; Maat, dkk., 2010; Riccomini, 2005; Seng, 2010; White, 2010; Yusof \& Malone, 2002).

Kesalahan matematika berdasarkan proses penyelesaian diklasifikasikan berdasarkan jenis masalah yakni, masalah perhitungan dan word-problem.Dalam menyelesaikan masalah perhitungan, Fong dan HoKheong (1993) mengklasifikasikan faktor penyebab kesalahan matematika dalam empat kategori, yaitu bahasa, operasional (ekternal dan internal), mathematical themes, dan psikologi.Yusof dan Malone (2002) menemukan jenis kesalahan matematika pada pecahan meliputi,grouping error, basic fact error, defective algorithm, incorrect operation dan careless error.Kiat (2005) mengklasifikasikan kesalahan dalam tiga kategori, yaitu kesalahan konseptual, kesalahan prosedural, dan kesalahan teknis.Elbrink (2007) menemukan bahwa kesalahan matematika pada siswa pendidikan menengah meliputi, kesalahan perhitungan, kesalahan prosedural, dan kesalahan simbolis.Godden, dkk.(2013) menemukan kesalahan matematika dalam penelitiannya berupa kesalahan karena ceroboh (teknis), prosedural, perhitungan, dan aplikasi. Herna (2018) menemukan kesalahan matematika dalam penelitiannya berupa kesalahan karena konseptual, prosedural, perhitungan, aplikasi, dan karena terjadi miskonsepsi.

Selanjutnya, dalam menyelesaikan word-problem, White (2010) mengkaji kesalahan matematika siswa berdasarkan analisis kesalahan Newman. Analisis kesalahan tersebut terdiri atas: reading error (kesalahan membaca), comprehension error (kesalahan pemahaman), transformation error (kesalahan transformasi), process error (kesalahan proses), danencoding error (kesalahan pengkodean).

Berdasarkan penelitian terkait kesalahan matematika di atas, peneliti menyimpulkan bahwa tipe kesalahan matematika yang dapat menyebabkan siswa mengalami kesulitan dalam mengonstruksi dan memecahkan masalah matematika dikelompokkan dalam sembilan kategori.Kategori tersebut meliputi, kesalahan memahami masalah (comprehension error), kesalahan konsep (concept error), kesalahan prosedur (procedure error), kesalahan fakta dasar (basic fact error), kesalahan prinsip (principle error), kesalahan penghitungan (calculation error), kesalahan aplikasi (application error), kesalahan kecerobohan (Careless error), kesalahan pemanggilan/mengingat (recalling error), dan kesalahan pengaitan(relating error). Dalam penelitian ini, tipe kesalahan ini yang nantinya akan digunakan dalam mengkaji proses terjadinya konstruksi pseudo ketika siswa mengonstruksi konsep dan memecahkan masalah matematika.

Proses konstruksi konsep matematika tidak terlepas dari pengetahuan dan pengalaman sebelumnya dari siswa. Hal ini sejalan dengan pendapat De Lima dan Tall (2008), McGowen dan Tall (2010), dan Tall $(2002,2004)$, bahwa dalam mengonstruksi pengetahuan baru, pengetahuan dan pengalaman sebelumnya yang disebut Tall sebagai met-before, dapat memberikan efek yang positif maupun negatif. Efek negatifnya adalah met-before dapat menyebabkan konflik yang serius. Hal tersebut dimaksudkan bahwa met-before dapat memicu terjadinya kesalahan dalam mengonstruksi konsep dan memecahkan masalah matematika. Untuk itu, dalam penelitian ini salah satu aspek yang akan dikaji untuk mengetahui sumber terjadinya konstruksi pseudo dalam mengonstruksi konsep dan memecahkan masalah matematika adalah met-before siswa.

Kesulitan dalam mengonstruksi suatu konsep akan menyebabkan kesulitan dalam mengonstruksi konsep matematika yang lain. Hal ini disebabkan karena konsep matematika yang satu memiliki keterkaitan dengan konsep matematika yang lain. Akibatnya, hal tersebut menyebabkan kurangnya pemahaman siswa pada objek matematika, dan pada akhirnya menyebabkan siswa mengalami kesulitan dalam memecahkan masalah matematika.

Hal di atas sejalan dengan pendapat Maat, dkk.(2010) bahwa kesalahan siswa dalam memecahkan persamaan kuadrat disebabkan mereka lemah dalam menguasai topik-topik seperti aljabar, pecahan, bilangan negatif, dan ekspansi aljabar. Sebagai contoh, ketika siswa melakukan kesalahan dalam menyelesaikan operasi bentuk aljabar dengan menjumlahkan atau mengurangkan suku aljabar yang tidak sejenis, maka siswa pun akan melakukan kesalahan yang sama ketika menyelesaikan persamaan kuadrat. Hal tersebut dikarenakan persamaan kuadrat memuat bentuk aljabar yang terdiri atas operasi suku-suku aljabar.

Penelitian ini mengkaji operasi penjumlahan bentuk aljabar maka kajian kesalahan dalam mengonstruksi penyelesaian soal matematika didasarkan pada kecenderungan pengetahuan prosedural.Sahdra \& Thagard (2003) mengatakan "pengetahuan prosedural adalah bagaimana tentang berpikir", meskipun banyak guru yang menilai hasil kinerja siswa dengan hanya melihat pengetahuan prosedural saja tetapi sebenarnya langkah demi langkah yang dilakukan siswa merupakan hasil keterampilan dan berpikir siswa. Meskipun hanya bersifat 
prosedural tetapi siswa membutuhkan proses dalam memahami langkah demi langkah dari kegiatan yang dilakukannya. Sejalan dengan itu Willingham, Nissen \& Bullemer (1989) mengatakan bahwa "pengetahuan prosedural itu adalah pengetahuan menjelaskan bagaimana melakukan tindakan dalam kerangka prosedur yang jelas".

Terkait dengan pernyataan di atas, kesalahan siswa dalam mengonstruksi dan memecahkan masalah/menyelesaikan soal matematikaperlu diperbaiki.Langkah awalnya adalah dengan mengetahui terlabih dahulu karakteristik konstruksi pseudo dalam menyelesaikan masalah matematika berdasarkan kecenderungan pengetahuan prosedural.

\section{METODE PENELITIAN}

Jenis penelitian yang digunakan adalah penelitian deskriptif. Hal ini dimaksudkan karena penelitian ini mendeskripsikan karakteristik dan proses terjadinya konstruksi pseudo berdasarkan kecenderungan pengetahuan prosedural. Pendekatan yang digunakan adalah pendekatan kualitatif, karena penelitian ini mengkaji proses atau tingkah laku siswa dalam menyelesaikan masalah matematika.

Penelitian ini dilakukan pada siswa kelas VIII SMP Negeri 1 Tinambung, kabupaten POLMAN provinsi SULBAR pada semester genap 2018/2019. Dalam penelitian ini, hasil pekerjaan siswa dalam menyelesaikan soal dibagi dalam dua kelompok berdasarkan jawaban siswa. Kelompok tersebut adalah kelompok jawaban benar,dan jawaban salah. Siswa yang akan digunakan dalam penelitian ini adalah siswa dari masing-masing kelompok tersebut yang berada dalam kondisi konstruksi pseudo (pseudo benar dan pseudo salah). Siswa dikatakan berada pada kondisi pseudo benar jika jawaban siswa benar dalam menyelesaikan lembar tugas, tetapi tidak mampu memberikan justifikasi terhadap prosedur yang digunakan. Siswa dikatakan berada dalam kondisi konstruksi pseudo salah jika jawaban siswa salah dalam menyelesaikan lembar tugas, tetapi sebenarnya siswa mampu menyelesaikan soal dengan benar dan mampu memberikan justifikasi terhadap prosedur yang digunakan setelah peneliti memunculkan disequilibrasi dalam dirinya.

Teknik pengumpulan data yang digunakan adalah dengan Think Alouds dan wawancara.Think Alouds dimaksudkan untuk data proses terjadinya konstruksi pseudo yang meliputi, data tulis, verbal, dan perilaku (ekspresi). Sedangkan wawancara dimaksudkan untuk mengkonfirmasi jika ada hal yang tidak jelas selama pengumpulan data dengan Think Alouds.

Proses analisis data dalam penelitian ini dilakukan dengan langkah-langkah sebagai berikut: (1) mentranskrip data verbal dan data prilaku (ekspresi) yang terkumpul, (2) menelaah seluruh data yang tersedia dari berbagai sumber, yaitu dari data tertulis, data verbal (hasil think out louds, dan wawancara (jika ada)), dan data prilaku (ekspresi) siswa, (3) mengadakan reduksi data dengan membuat abstraksi. Abstraksi merupakan usaha membuat rangkuman yang inti, proses, dan pernyataan-pernyataan yang perlu dijaga untuk tetap berada di dalamnya, (4) menyusun dalam satuan-satuan yang selanjutnya dikategorisasikan dengan membuat coding, (5) menggambarkan struktur berpikir siswa dalam menyelesaikan masalah pada lembar tugas.

\section{HASIL DAN PEMBAHASAN}

Contoh Permasalahan :

Menyelesaikan bentuk aljabar

$$
\frac{3 a}{5}+\frac{4 a}{3}=\ldots
$$




\section{Struktur Masalah}

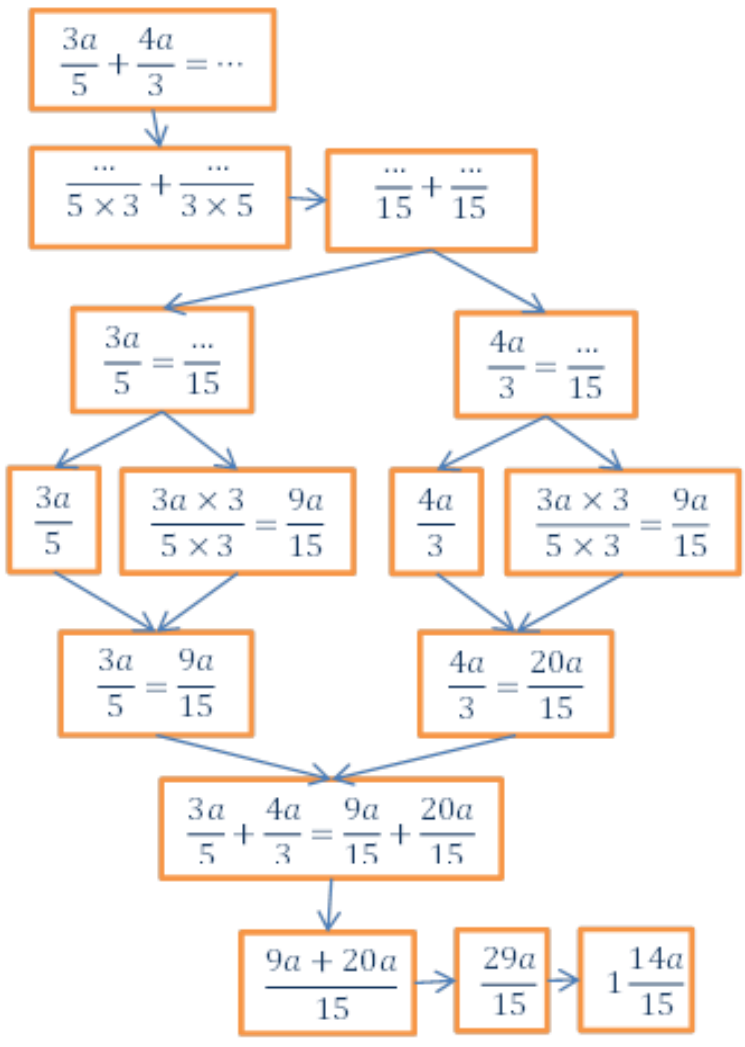

\section{Konstruksi Pseudo Benar (KPB)}

Berikut struktur berpikir salah satu subjek yang mengalami konstruksi pseudo benar ketika menyelesaikaninstrumen soal di atas.

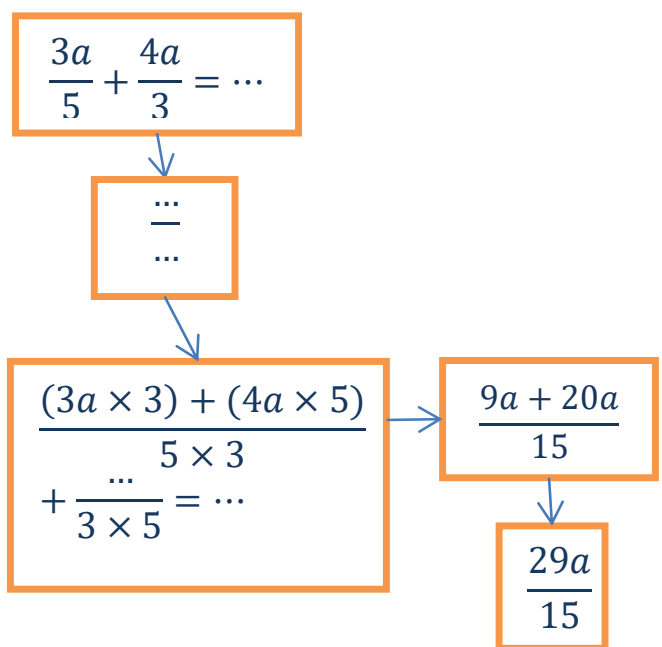


Struktur berpikir di atas menyatakan bahwa siswa menyelesaikan soal operasi penjumlahan bentuk aljabar dengan menggunakan prosedur yang benar yakni, dengan mengalikan masing-masing penyebut pecahan yang akan dijumlahkan untuk menentukan penyebut, dan menentukan pembilang dengan menjumlahkan hasil perkalian silang antara pembilang dan penyebut dari pecahan-pecahan tersebut.

Lebih lanjut dinyatakan bahwa siswa memperoleh jawaban yang benar tetapi tidak bisa memberikan justifikasi terhadap prosedur yang digunakan (Herna, dkk., 2016; Subanji, 2007, 2011; Vinner,1997). Sebagai contoh, ketika siswa ditanya alasannya mengalikan masing-masing penyebut pecahan yang akan dioperasikan yakni, bilangan 5 dan 3, siswa menjawab "karena seingat saya begitu caranya kalau mau menjumlahkan pecahan". Demikian terus jawaban siswa ketika diminta memberikan justifikasi pada prosedur yang digunakan untuk menyelesaikan soal.

Setelah dikaji lebih mendalam melalui wawancara, ternyata siswa tidak menggunakan pengetahuan yang siswa peroleh sebelumnya seperti, aturan penjumlahan pecahan bentuk aljabar dimana pembilang dapat dijumlahkan ketika penyebut masing-masing pecahan yang akan dioperasikan sama, konsep pecahan senama dan senilai, konsep bentuk aljabar dan operasinya. Siswa cenderung menghafal prosedur dan bekerja berdasarkan pengalaman sebelumnya ketika menyelesaikan operasi penjumlahan pecahan bentuk numerik.

\section{Konstruksi Pseudo Salah Tipe $1\left(\mathrm{KPS}_{1}\right)$}

Berikut struktur berpikir salah satu subjek yang mengalami konstruksi pseudo salah ketika menyelesaikan instrumen soal.

$$
\begin{gathered}
\frac{3 a}{5}+\frac{4 a}{3}=\cdots \\
\frac{\frac{3 a+4 a}{5+3}}{\downarrow} \\
\frac{7 a}{8}
\end{gathered}
$$

Setelah peneliti melakukan wawancara mendalam terhadap subjek, peneliti mengetahui bahwa subjek secara spontan menjawab soal di atas dengan menjumlahkan pembilang dengan pembilang dan penyebut dengan penyebut karena mengingat aturan perkalian pecahan.Hal ini sejalan dengan penelitian yang dilakukan oleh Herna (2018) dan berarti subjek melakukan recalling error (Fong\& Ho-Kheong, 1993). Hasil yang diperoleh adalah $\frac{3 a+4 a}{5+3}=\frac{7 a}{8}$, jawaban ini merupakan jawaban yang salah. Akan tetapi, setelah melakukan refleksi terhadap jawabannya, subjek mampu menemukan jawaban yang benar.Kondisi ini sesuai dengan pseudo Analytic oleh Vinner (1997).subjek menyelesaikan soal dengan menggunakan prosedur penyelesaian yang benar, dan mampu memberikan justifikasi terhadap prosedur yang digunakan.Hal ini sejalan dengan prilaku analitik oleh Vinner (1997). 


\section{Konstruksi Pseudo Salah Tipe 2 (KPS 2$)$}

Berikut struktur berpikir salah satu subjek yang mengalami konstruksi pseudo salah tipe 2 ketika menyelesaikan instrumen soal.

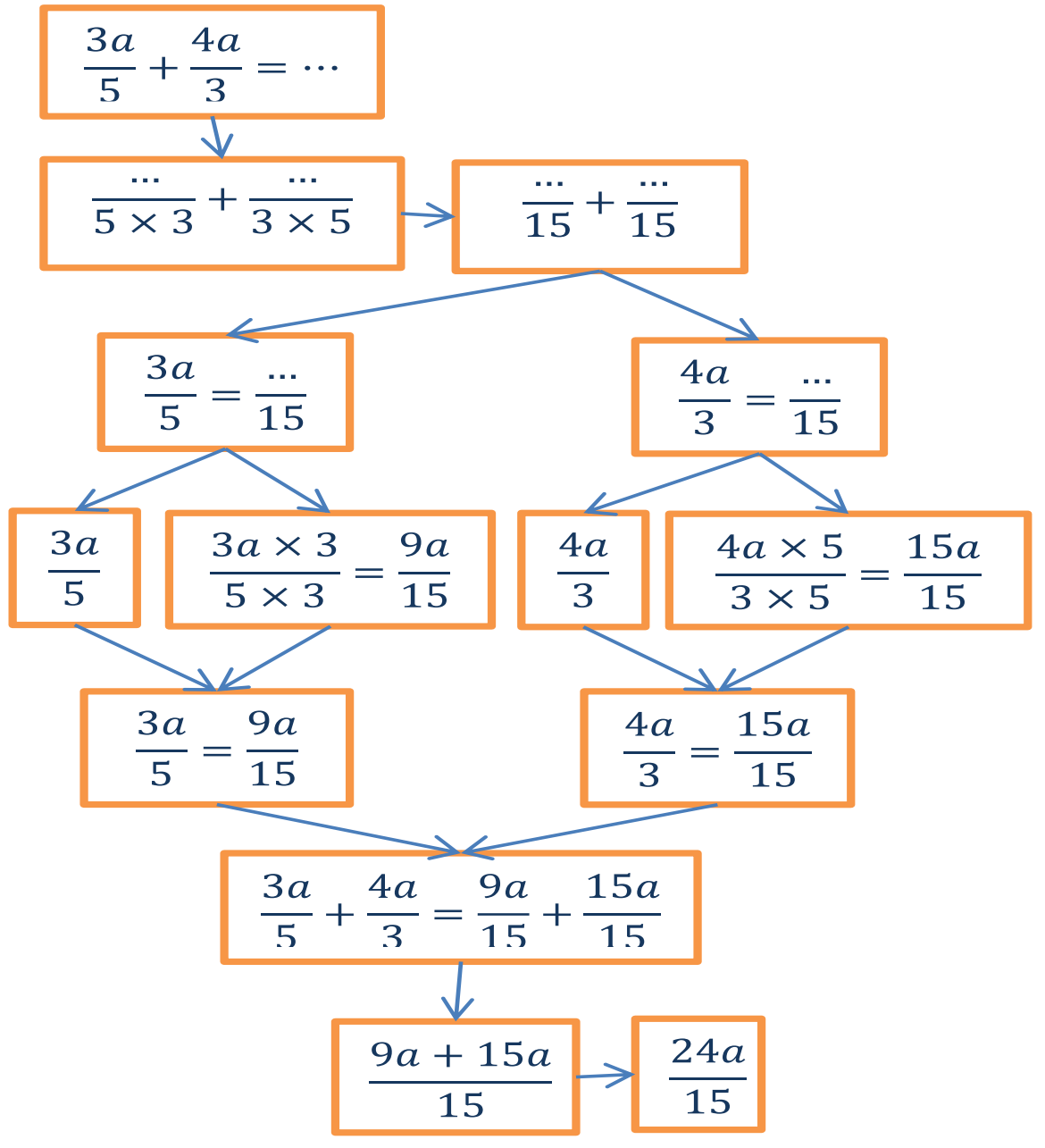

Struktur berpikir subjek di atas sesuai dengan struktur masalah, tetapi subjek menemukan jawaban yang salah.Hal ini menunjukkan bahwa subjek menyelesaikan soal dengan menggunakan prosedur yang benar dan mampu memberikan justifikasi terhadap prosedur yang digunakan.Hal ini sesuai dengan prilaku analitik oleh Vinner (1997).Akan tetapi, subjek menemukan jawaban yang salah karena melakukan kesalahan dalam mengaplikasikan prosedur penyelesaian, yakni calculation error yang diakibatkan oleh kecerobohannya (Elbrink, 2007). Kesalahan tersebut juga ditemukanoleh Herna (2018) ketika mengkaji kesalahan siswa dalam menyelesaikan soal penjumlahan pecahan bentuk aljabar.Hal ini berarti subjek berada dalam kondisi konstruksi pseudo salah (Subanji, 2007, 2011).Kesalahan itu terjadi ketika subjek mengalikan 4a dengan 5 dimana diperoleh 15a.Meskipun begitu, setelah melakukan refleksi, subjek mampu memperbaiki kesalahannya dan menemukan jawaban yang benar(Saler \& Edgington, 2006).

Peneliti menemukan beberapa karakteristik dalam menyelesaikan soal operasi penjumlahan bentuk aljabar berdasarkan kecenderungan pengetahuan prosedural.Berikut bagan yang mendeskripsikan karakteristik tersebut. 
Karakteristik konstruksi pseudo dalam menyelesaikan soal operasi penjumlahan bentuk aljabar berdasarkan kecenderungan pengetahuan prosedural

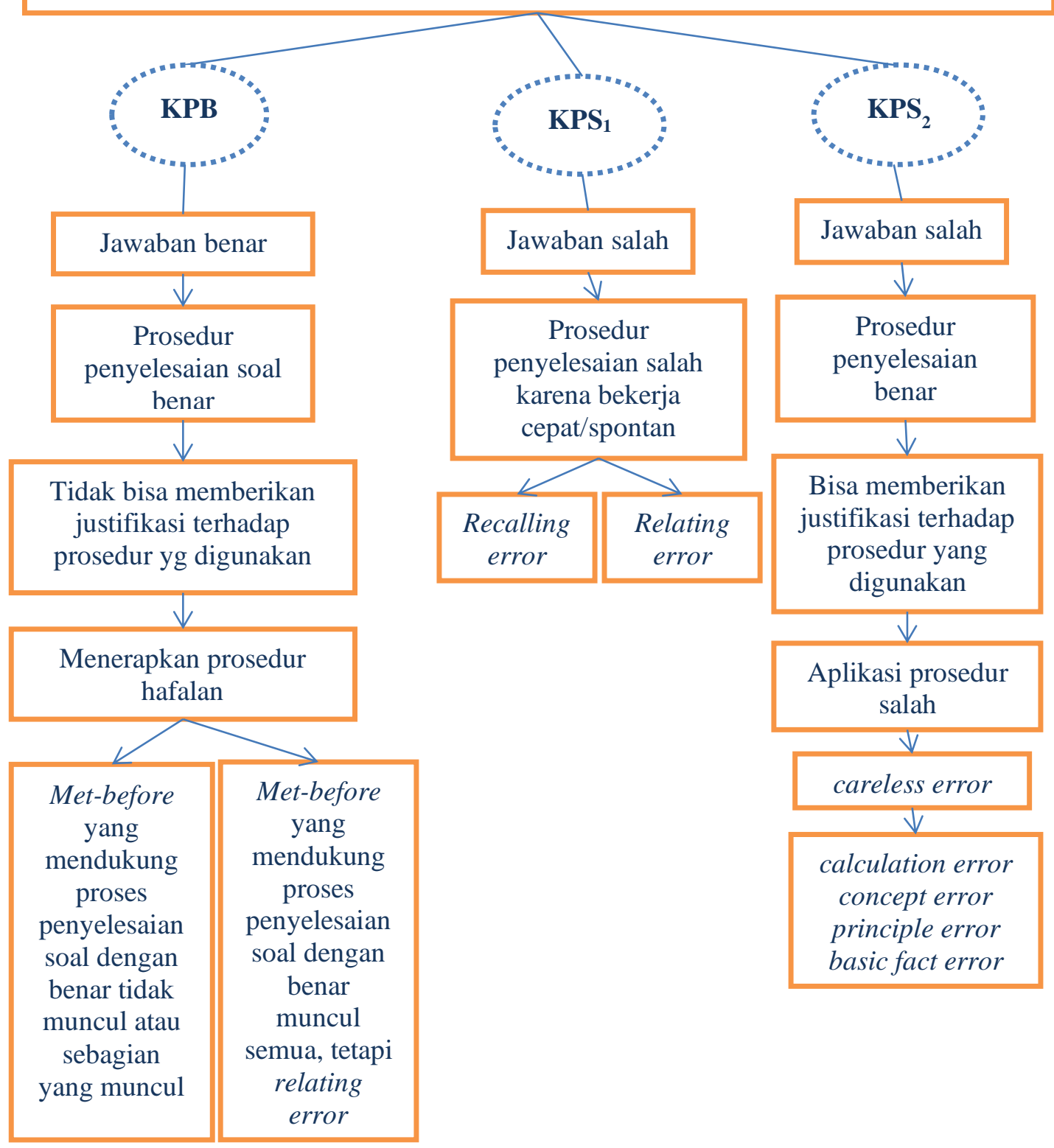

\section{KESIMPULAN}

Berdasarkan hasil penelitian dan pembahasan sebelumnya, peneliti menyimpulkan bahwa dalam menyelesaikan soal matematika berdasarkan kecenderungan pengetahuan prosedural, siswa memiliki beberapa karakteristik.Berikut adalah karakteristik yang dimaksudkan.

Pertama, Konstruksi pseudo benar terjadi ketika siswa menyelesaikan soal matematikadimanaia memberikan jawaban yang benar dengan prosedur penyelesaian yang benar, tetapi siswa tidak mampu memberikan justifikasi terhadap prosedur yang digunakan. Penyebabnya adalah met-before yang mendukung proses penyelesaian soal dengan benar tidak muncul atau sebagian yang muncul, dan met-before yang mendukung proses penyelesaian soal dengan benar muncul semua tetapi relating error.

Kedua, Konstruksi pseudo salah terjadi dalam dua kondisi.Pertama, kondisi ketika siswa memberikan jawaban yang salah dengan prosedur penyelesaian yang salah, karena siswa terdorong untuk menjawab dengan 
https://jurnal.unsulbar.ac.id/index.php/saintifik

cepat.Kedua, kondisi ketika siswa memberikan jawaban yang salah karena careless error dengan prosedur penyelesaian yang benar, dan siswa mampu memberikan justifikasi terhadap prosedur yang digunakan.

\section{DAFTAR PUSTAKA}

Barrera, dkk. 2004. Cognitive Abilities and Errors of Students in Secondary School in Algebraic Language Processes. Proceedings of the twenty-sixth annual meeting of the North American Chapter of the International Group for the Psychology of Mathematics Education. Volume 1.

Dhlamini. 2014. Grade 9 Learners' Errors and Misconceptions In Addition of Fractions.Mediterranean Journal of Social Sciences.Vol 5, No. 8, ISSN 2039-2117 (online) ISSN 2039-9340 (print). Publishing: MCSER

Elbrink. 2007. Analyzing and Addressing Common Mathematical Errors in Secondary Education. B.S. Undergraduate Mathematics Exchange, Vol. 5, No. 1.

Ganesan \& Dindyal. 2014. An Investigation of Students' Errors in Logarithms. Proceedings of the 37th annual conference of the Mathematics Education Research Group of Australasia. pp. 231238. Sydney: MERGA.

Godden, dkk. 2013. An Analysis of Errors and Misconceptions inThe 2010 Grade 12 Mathematics Examination: A Focus On Quadratic Equations And Inequalities. Proceedings of the 19th Annual Congress of the Association for Mathematics Education of South Africa.Vol. 1. (pp. 70 - 79). Cape Town: AMESA.

Herna. 2018. Analisis Kesalahan Matematika Siswa dalam Menyelesaikan Soal Operasi Penjumlahan Pecahan Bentuk Aljabar. Jurnal Pendidikan PEPATUDZU. Vol. 13, No. 1,p-ISSN: 2087-3476, eISSN: 2541-5700.

Herna, Nusantara, T., Subanji, \&Mulyati, S. 2016. The characterization of True Pseudo Construction in Understanding Concept of Limit Function. IOSR Journal of Research \& Method in Education (IOSR-JRME). Vol. 6, Issue 5 Ver. III, pp. 77-87, e-ISSN: 2320-7388, p-ISSN: 2320-737X.

Huang \& Cheng. 2010. Analyzing Errors Made by Eighth-Grade Students in Solving Geometrical Problems in China. The Mathematics Educator. Vol. 12, No.2, 63-80.

Idris \& Narayanan. 2011. Error Patterns in Addition and Subtraction of Fractions among Form Two Students.Journal of Mathematics Education. Vol. 4, No. 2, pp. 35-54.

Kahneman, D. 2002. Maps of Bounded Rationality: A Perspective on Intuitive Judgment and Choice, in Les Prix Nobel, Edited by. T. Frangsmyr, pp. 416-499.

Kiat. 2005. Analysis of Students' Difficulties in Solving Integration Problems. The Mathematics Educator. Vol. 9, No.1, 39-59.

Leron, U. 2004. Intuitif versus Analytical Thinking: Four Theoretical Frameworks.

Lithner, J. 2000. Mathematical Reasoning in Task Solving. Educational Studies in Mathematics, Vol 41, pp. 165-190. 
Maat, dkk. 2010. Analysis of Students' Error in Learning of Quadratic Equations. International Education Studies. Vol. 3, No. 3.

McGowen, M. \& Tall, D. O. 2010.Metaphor or Met-before?The effects of previous experience on the practice and theory of learning mathematics.Journal of MathematicalBehavior 29, 169-179.

Pape, J. Steven. 2004. Middle School Children's Problem Solving Behavior: A Cognitive Analysis from A Reading Comprehension Perspective.Journal for Research in Mathematics Education, $35(3)$.

Riccomini. 2005. Identification and Remediation of Systematic Error Patterns In Subtraction. Summer.Volume 28.

Sahdra, B. \& Chand, I. 2003.Procedural Knowledge in Molecular Biology, Philosophical Psycology. Vol. 16, No. 4, pp. 477-498.

Saler, G. \& Edgington, G.C. 2006. Piaget WebQuest.

Subanji. 2007. Proses Berpikir Penalaran Kovariasional Pseudo dalam Mengkonstruksi Grafik Fungsi Kejadian Dinamika Berkebalikan. Disertasi tidak dipublikasikan, Surabaya: Program Pascasarjana UNESA.

Subanji. 2011. Teori Berpikir Pseudo Penalaran Kovariasional. Malang: Universitas Negeri Malang.

Subanji \& Nusantara, T. 2013.Karakterisasi Kesalahan Berpikir Siswa dalam Mengkonstruksi Konsep Matematika.Jurnal Ilmu Pendidikan, 19(2), hal. 129-251.

Vinner, S. 1997. The Pseudo-conceptual and The pseudo-analytical thought Processes in Mathematics Learning. Educational Studies in Mathematics 34, pp. 97-129.

Vinner, S. 2000. Mathematics Education-Procedures, Rituals and Man's Search for Meaning. Ben Gurion University of the Negev, A regular lecture given at ICME 9, Japan.July 31 - August 6.

White. 2010. Numeracy, Literacy and Newman's Error Analysis. Journal of Science and Mathematics Education in Southeast Asia. Vol. 33, No. 2, 129-148.

Yusof \& Malone. 2002. Mathematical Errors in Fractions: A Case of Bruneian Primary 5 Pupils. University of Technology. 